\section{Congress turn}

As part of a general effort to cut the foreign aid budget, Congress is threatening to veto the major US contribution to the new international fund for science and technology in developing countries which was set up following last year's United Nations Conference on Science and Technology for Development (UNCSTD).

The House of Representatives Appropriations Committee last week recommended the elimination from the 1981 budget request of a $\$ 10$ million contribution which the Carter administration had proposed for the new fund. The committee also proposed changing the foreign aid bill so as to prevent any of the $\$ 130$ million allocated to the United Nations Development Programme - the agency handling the fund - being used for this purpose.

UNDP officials hope that these recommendations will be rejected when the full House debates the foreign aid bill. Otherwise they fear that withdrawal of the US contribution could put the whole fund in jeopardy. This, they warn, would have repurcussions for relationships between the US and the many countries - particularly in Africa - which have already submitted project proposals to the fund on the understanding that adequate support has been promised.

Delegates to the UNCSTD conference in Vienna last August agreed to the fund as an interim measure. Initially the developing countries had proposed a more ambitious scheme for a $\$ 2,000$ million to $\$ 4,000$ million annual tax on technology transfers from the developed nations, but this was quickly rejected as unrealistic.

Promises were, however, made to explore the long-term prospects for such a scheme. Meanwhile a two-year interim fund was proposed under the auspices of the UNDP, with an initial target set at $\$ 250$ million, of which the US indicated it would be prepared to cover 20 to 25 per cent.

In practice, even this target turned out optimistic. At a meeting in New York in March, total pledges of $\$ 36$ million were made, primarily by Austria, Denmark, Norway, Sweden, The Netherlands and the US. (The UK made it clear in Vienna that it was not prepared to contribute: France and Germany are still negotiating conditions under which they may give up to $\$ 9$ million more.)

Even though the total was less than had been hoped for, the UNDP decided that enough had been raised to get the fund off the ground. With the support of the UN General Assembly, the fund officially became operational in May. UNDP has already received over 550 applications from the governments of developing countries, and 70 projects have been selected as candidates for funding.

One African country has approached the

UNDP for joint funding of a new metallurgical research institute, and another eight are already including possible support from the UNDP in schemes to integrate science and technology policies into their five-year economic plans.

UNDP officials argue that for the US to withdraw its proposed contribution - given its central role in engineering the Vienna compromise and steering attention away from the more far-reaching third world demands - would not only prejudice the future of the fund itself, but would also cast a cloud over all future negotiations on overseas aid.

The proposed $\$ 10$ million US contribution has already been endorsed by the science committees and the foreign affairs committees in both the House and the Senate. Indeed some congressmen say they would have been prepared the support the $\$ 15$ million contribution which President Carter had proposed in his original January request.

Despite this support, however, the appropriations committees are proving harder to convince. Commenting on its proposal that the US should not contribute to the fund, the House Appropriations Committee says that it took the action because the Administration had failed to provide adequate information on the activities of the fund.

\title{
Compromise for Finniston?
}

On the principle that ministers cannot go on holiday until parliament has seen that their desks are clear, the British government was earlier this week preparing its much-delayed response to the report of the Finniston Committee on engineering education. The response will lose some friends and make some enemies, but is otherwise likely to be a compromise.

The central issue to have become apparent since the committee's report was published earlier this year is whether responsibility for the education of professional engineers, including the accreditation of university and other courses, the definition of professional standards and the certification of those claiming them, should rest with a new public body to be called the British Engineering Authority.

The Finniston Committee argued that there should be such a body, which would inevitably take over from the separate engineering institutions many of their existing educational and professional responsibilities. The committee also asked that such a body should be statutory, responsible to the minister responsible for industry - for the time being Sir Keith Joseph, Secretary of State for Industry. Only by such a device, the committee argued, could the reorganization of engineering education and qualification be
This information is now being hastily provided, in the hope that at least some members of the Appropriations Committee can be persuaded to change their position. But the UNDP contribution has also become tied up with the conflict between the Congress and the Administration over the latter's plan to set up an Institute for Scientific and Technical Cooperation (ISTC) as a focus for research relevant to developing countries.

Last year Congress accepted the ISTC proposal in principle, but the appropriations committees failed to allocate funds after a bitter fight over the form that the institute should take, and its relationship to existing scientific and technological programmes in the Agency for International Development.

This year the Administration has again put forward the ISTC for funding. But despite plans to reduce its scope it seems increasingly unlikely that the institute will get off the ground.

Such a failure, embittered as it would be by the disputes which there have been between the Administration and Congress about overseas aid and the growing' hostility of Congress towards multilateral aid programmes, imply that supporters of the UNDP have an uphill task ahead of them.

David Dickson

carried out in such a way that industry could take notice. The committee also recognized that even the British government has, on paper at least, a long purse.

Since the publication of the report in February, the Department of Industry has invited comments from no fewer than 400 interested parties, most of whom have apparently replied. Many respondents, the Confederation of British Industries and the Committee of Vice-Chancellors and Principals for example, have however disappointed members of the Finniston Committee by warning the government against the notion that the engineering profession should be regulated directly by the government. This advice is likely to be the more influential because those who offer it also welcome structural changes in engineering education and qualification.

The favourite compromise seems to be that there should indeed be a new authority responsible for engineering education, but that it should be set up as an autonomous institution by the Privy Council, not by the government as such. To begin with, there should be a measure of direct financial help from the British government, but in the long run it might be appropriate that support should be channelled through bodies such as the University Grants Committee. 